\title{
The impact on the equity value of listed companies pledge - A Case Study of La Chapelle
}

\author{
Fang Liu ${ }^{1, a *}$ \\ ${ }^{1}$ School of Finance, Shandong Technology and Business University, Yantai, China
}

\begin{abstract}
With the rapid development of China's securities market, bank loans as an important channel of enterprise financing has been unable to meet the capital needs of most enterprises, this article is based on the A-share main board listed company and equity pledge ratio as the research object, a case study of rashabel's equity. It is concluded that the value of the company is inversely proportional to the proportion of the allocated equity. We should distribute equity reasonably, balance the power among shareholders, so as to improve the efficiency of governance and strengthen the supervision of large shareholders.
\end{abstract}

\section{Introduction}

Equity pledge refers to the behavior of controlling shareholders to pledge their shares to the fund lender to obtain loans[1]. During the period of stock pledge, the controlling shareholders can not sell the Pledged Shares, but can get the cash dividend distribution of the company. During the holding of the shareholders' meeting, they can also enjoy the corresponding voting rights. Before the maturity date of the loan, the pledger of the equity needs to return the principal and interest to the lender in accordance with the contract, Changes in the RMB exchange rate also have a certain impact on economic growth[2] and at the same time dissolve the pledged stocks on the stock exchange. However, if the equity pledgor fails to repay all the debts within the agreed time, the lender has the right to apply to the securities registration authority for changing the shareholders of the Pledged Shares, that is, the ownership of the pledge object belongs to the lender, at the same time, the pledgor of the equity will lose the identity of the shareholder, and the pledge of the stock right is the behavior of the shareholder, which has no direct connection with the company, However, as the owners of the company, shareholders' equity pledge related behavior will indirectly transfer the company's relevant business information to the outside world, which will have an impact on the value of the company.

With the deepening of China's economic marketization, equity pledge is becoming more and more common in China. Through equity pledge, the controlling shareholders can raise funds for the company in a short time, and then broaden the financing channels of the company. General corporate financing is divided into internal financing and external financing. Internal financing refers to the way that a company keeps its net profit in the past years. However, when there are losses for many years, the company will not be able to raise funds internally. External financing means that companies inject capital into the company by attracting external equity investors, or borrow money from banks and other financial institutions. Raise the necessary funds for the company from the external capital market. When the company's operating scale is small or the profitability is poor, it can borrow money from the lender through the equity pledge of the controlling shareholder. At the same time, the Pledged Shares can circulate freely in the securities market, the lender may inquire about the price of the underlying stock, compared with the traditional way of borrowing, the process of equity pledge is simple, therefore, the majority shareholders can raise funds for the company to maintain operation and management through the pledge of equity.

\section{The impact of equity pledge on company value}

For the reasons of equity pledge of listed companies, most scholars believe that equity pledge can help enterprises relieve liquidity pressure and increase the value of the company by improving the management level of the company. Jiang Xiaowen's (2019) research shows that compared with state-owned listed companies, shareholders of private listed companies are more inclined to use the listing platform for equity pledge financing due to financing constraints[3]. This kind of positive incentive is helpful to improve the company's performance, which can be understood as the listed company to improve the company's value by controlling the high-risk investment projects for steady operation. In fact, this is also the behavior of market value management. Mingyue, Zhang Qing et al. (2020) through empirical research in Shanghai and Shenzhen stock markets[4], show that shareholders of listed companies are more active in market value management after equity

a* Fang Liu: 392131080@qq.com 
pledge financing. Li Changqing and Xing Wei (2018) studied the behavior of shareholders' equity pledge from the perspective of the risk of stock price crash [5]. The research shows that the risk of stock price crash of the holding shareholder's equity pledge company is lower than that after the pledge is lifted, which shows that there is a strong negative correlation between equity pledge and stock crash risk[6].

From the perspective of financial management, Dai Zhixing et al. (2018) believe that the financial risk of listed companies transfers to other shareholders through equity pledge, which makes the company's operating level unstable, which causes the stock price to fall and causes equity pledge risk[7]. Chen $\mathrm{Na}$ (2017) believes that a company's financial leverage increases with the controlling shareholder's financial leverage, and an increase in financial leverage means that the company's asset-liability ratio increases[8]. When it is higher than the company's standard, the company's value may be lost, Loss of company value.

Through the analysis of the proportion of equity pledge, quite a number of studies show that a high proportion of equity pledge will have a negative impact on the company value [9]. The research of Shen Ping and Jingrui (2020) pointed out that a high proportion of equity pledge has a more significant negative impact on the company's value, and a high level of pledge means that the company has certain operating risks[10]. Wen Wen et al. (2018) found through empirical research that a high proportion of major shareholders' pledge will significantly reduce the company's performance level [11]. However, enterprises with good quality of internal control can offset this negative impact with internal control, playing a positive regulatory role[12].

\section{The path of equity pledge affecting company value}

\subsection{Influencing company value by improving company management}

Equity pledge behavior has gradually become a commonly used method of financing, but it does not mean that there are no disadvantages in equity pledge behavior. The pledge of controlling shareholders' equity is a double-edged sword for both shareholders and the company. The equity pledge behavior of large shareholders is conducive to strengthening the operation and management of the company, which is conducive to the promotion of the company's value. The equity held by major shareholders is a liquid asset that can be traded in the capital market, and its mortgage value depends on the company's current operating conditions and future profitability. The value of assets depends on the intrinsic value of assets. The company's stock price is often proportional to the company's value. In order to enhance the mortgage value and obtain a higher amount of financing, the controlling shareholders will strengthen the operation and management of the company, hoping to enhance the company's value and then raise the stock price.

Equity pledge can find shareholders with stronger management ability for the company, which can improve the company's management level and enhance the company's value. The amount that the shareholder cannot repay within the pledge period indicates that the shareholder has limited operating ability, and the company may consider replacing a shareholder with stronger ability. Therefore, equity pledge can promote the survival of the fittest, promote the improvement of corporate governance and enhance the value of the company.

\subsection{Influence the company value through the change of stock price in capital market}

The pledge behavior of controlling shareholders will also form the impression that the company's operation is getting worse for other investors, which is not conducive to the promotion of the company's value. The pledge behavior of major shareholders of listed companies will be released to the public through the public announcement of listed companies, which may make the company's central shareholders form the impression that the company has encountered difficulties in operation, and lead to selling behavior, resulting in the decline of stock price and company value, show in Table 1.

Table 1 A-share main board listed company equity pledge ratio

\begin{tabular}{cc}
\hline Equity pledge ratio & Number of listed companies \\
\hline 0 & 1405 \\
$>0 \sim 10$ & 819 \\
$>10 \sim 30$ & 1118 \\
$>30 \sim 50$ & 425 \\
$>50 \sim 70$ & 81 \\
$>70$ & 6
\end{tabular}

National Bureau of Statistics

To sum up, in the long run, shareholders' equity pledge will improve the management and enhance the value of the company, But in the short term, the panic of small and medium shareholders will lead to the chief investor out, which is not conducive to the promotion of the company's value. At the same time, equity pledge 
behavior does not necessarily lead to the decline of the company's share price within one year. The value of shareholder equity pledge varies from person to person, because different listed companies have different levels and abilities of operation and management. Because of the different solvency of shareholders to debts due to the operating conditions of listed companies, investors will make different reflection, which will bring about different influence degree of shareholder equity pledge on the company value [13].

\section{A case study of La Chapelle}

\subsection{La Chapelle's equity structure}

By the third quarter of 2020, the top ten shareholders of the company hold $41.16 \%$ of the total share capital of the company, and the controlling shareholder Xing Jiaxing holds 1.418 billion shares of rashabel, accounting for $25.91 \%$ of the total share capital of the company. Since its listing, Xing Jiaxing has been the largest shareholder of the company, holding more than half of the shares held by the top ten shareholders.

Table 2 Share structure of La Chapelle in the third quarter of 2020

\begin{tabular}{|c|c|c|c|}
\hline Shareholder & $\begin{array}{c}\text { Number of } \\
\text { shares held }\end{array}$ & $\begin{array}{c}\text { Proportion in total } \\
\text { share capital(\%) }\end{array}$ & Nature of share capital \\
\hline Jiaxing Xing & $141,874,425$ & 25.91 & Restricted A shares \\
\hline $\begin{array}{c}\text { Shanghai Hexia Investment Co., Ltd } \\
\text { Beijing Kuanjie Bohua Investment Center } \\
\text { (limited partnership) }\end{array}$ & $45,204,390$ & 8.25 & Restricted A shares \\
\hline $\begin{array}{c}\text { Shenzhen Defu United Financial Holding } \\
\text { Co., Ltd }\end{array}$ & $13,637,426$ & 2.49 & Circulating A shares \\
\hline Ling Chen & $7,345,200$ & 1.34 & Circulating A shares \\
\hline $\begin{array}{c}\text { Special securities account for repurchase of } \\
\text { Xinjiang lashabel Clothing Co., Ltd }\end{array}$ & $3,573,200$ & 1.05 & Circulating A shares \\
\hline Yong Liu & $2,177,300$ & 0.65 & Circulating A shares \\
\hline Dengfang Bai & $2,136,200$ & 0.40 & Circulating A shares \\
\hline Jianliang Chen & $1,870,000$ & 0.39 & Circulating A shares \\
\hline Zhimin Wu & $1,847,100$ & 0.34 & Circulating A shares \\
\hline Total & $225,433,167$ & 0.34 & \\
\hline
\end{tabular}

As shown in Table 2, rachabel's ownership structure is in a dominant position, with institutional investors such as financial companies, investment companies and banks accounting for $13.97 \%$ of the shares. At the same time, from the perspective of the nature of the company's share capital, it can be seen that the possibility of profit is small when the majority shareholders hold Limited shares. When the company has financial difficulties, it may be through equity pledge to finance.

\subsection{Analysis on the profitability of La Chapelle}

By analyzing the profitability of listed companies, we can see whether the equity pledge behavior of major shareholders will have a negative impact on the profitability of the company [14]. This article analyzes La Chapelle's profitability by comparing La Chapelle's total net profit rate, return on net assets, industry average net profit rate, and industry average return on net assets.

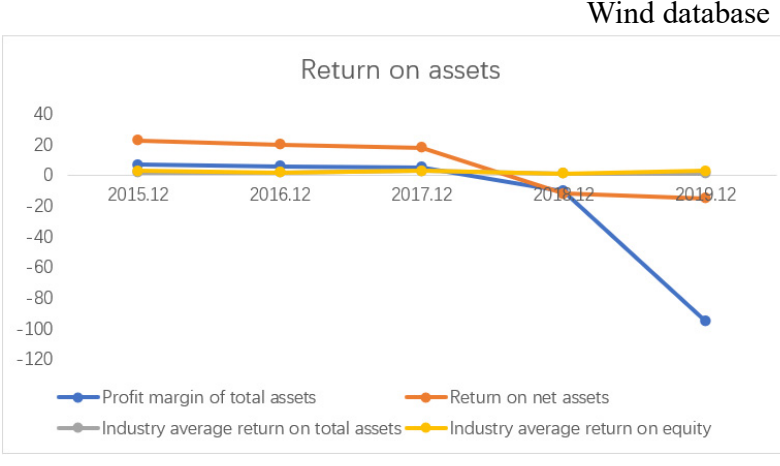

Fig. 1. Trend of return on total assets and return on net assets

As shown in Figure 1, La Chapelle's return on net assets from 2015 to 2017 was higher than the industry average, but since 2017, the return on assets has been on a downward trend, it shows that the level of return on equity of enterprises is lower. Since 2017, the net profit of the company has decreased from 490 million yuan to 2.2 billion yuan in 2019, and the profitability has decreased, indicating that the performance of the listed company has declined after the equity pledge. At the same time, the company has made profits and losses for two consecutive years, and now it has become a st share. 


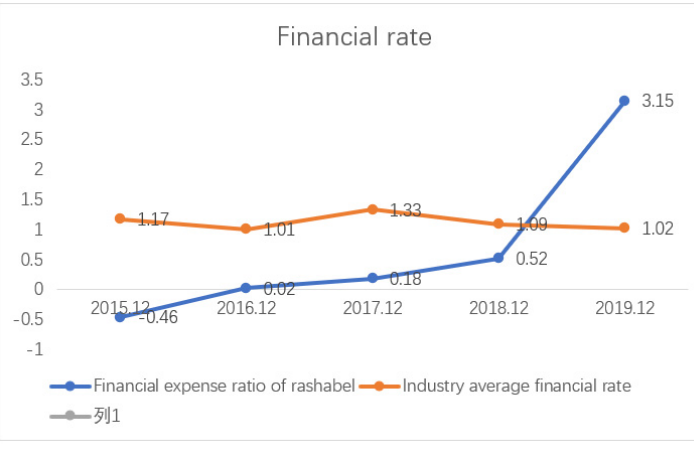

Fig. 2. Financial expenses

As shown in Figure 2, La Chapelle's financial expenses accounted for a large proportion of its main business income, and the company's profitability was insufficient and financial difficulties were under pressure. Before 2018, the financial expenses of rachabel have been lower than the average value of the industry. However, in 2019, the financial expenses increased significantly, which may be that the major shareholders encroached on the company's profits through equity pledge, and transferred the risk to the listed companies

\subsection{Separation degree of control right and cash flow right}

A large number of studies have shown that the agency problems caused by the control right and cash flow right of the major shareholders after the equity pledge aggravate their interest encroachment, during the pledge period, with the increase of the amount of pledge, the controlling shareholder's control right remains unchanged, but the cash flow right will decrease with the increase of the amount of pledge. According to the announcement of La Chapelle company, this paper determines the difference between the control right and the cash flow right of the major shareholders after the equity pledge through the calculation method of the control right and the cash flow right.

Table 3 Separation degree of control right and cash flow right

\begin{tabular}{ccccccccc}
\hline & \multicolumn{3}{c}{ Before equity pledge } & \multicolumn{5}{c}{ After equity pledge } \\
& $\mathrm{V} 1$ & $\mathrm{C} 1$ & $\mathrm{~V} 1-\mathrm{C} 1$ & $\mathrm{~V} 1 / \mathrm{C} 1$ & $\mathrm{~V} 2$ & $\mathrm{C} 2$ & $\mathrm{~V} 2-\mathrm{C} 2$ & $\mathrm{~V} 2 / \mathrm{C} 2$ \\
\hline $2017-11-28$ & $34.16 \%$ & $34.16 \%$ & $0.00 \%$ & 1.00 & $34.16 \%$ & $27.77 \%$ & $6.39 \%$ & 1.23 \\
$2017-12-07$ & $34.16 \%$ & $34.16 \%$ & $0.00 \%$ & 1.00 & $34.16 \%$ & $20.47 \%$ & $13.69 \%$ & 1.67 \\
$2018-05-08$ & $34.16 \%$ & $34.16 \%$ & $0.00 \%$ & 1.00 & $34.16 \%$ & $16.45 \%$ & $17.71 \%$ & 2.08 \\
$2018-09-18$ & $34.16 \%$ & $34.16 \%$ & $0.00 \%$ & 1.00 & $34.16 \%$ & $13.71 \%$ & $20.45 \%$ & 2.49 \\
$2018-10-17$ & $34.16 \%$ & $34.16 \%$ & $0.00 \%$ & 1.00 & $34.16 \%$ & $10.60 \%$ & $23.56 \%$ & 3.22 \\
$2018-10-18$ & $34.16 \%$ & $34.16 \%$ & $0.00 \%$ & 1.00 & $34.16 \%$ & $9.69 \%$ & $24.47 \%$ & 3.53 \\
$2019-01-31$ & $34.16 \%$ & $34.16 \%$ & $0.00 \%$ & 1.00 & $34.16 \%$ & $5.13 \%$ & $29.03 \%$ & 6.66 \\
$2019-02-01$ & $34.16 \%$ & $34.16 \%$ & $0.00 \%$ & 1.00 & $34.16 \%$ & $4.12 \%$ & $30.04 \%$ & 8.29 \\
$2019-06-10$ & $34.16 \%$ & $34.16 \%$ & $0.00 \%$ & 1.00 & $34.16 \%$ & $2.38 \%$ & $31.78 \%$ & 14.35 \\
$2019-08-05$ & $34.16 \%$ & $34.16 \%$ & $0.00 \%$ & 1.00 & $34.16 \%$ & $1.28 \%$ & $32.88 \%$ & 26.69 \\
\hline
\end{tabular}

China has not yet promulgated the corresponding laws to

According to Table 3, after the major shareholders of La Chapelle pledged their equity, the degree of separation between control rights and cash flow rights gradually deepened. From the beginning of 1.5842 rose to the highest 96.9336, an increase of 60 times. At present, the cash flow rights of major shareholders are close to zero, It shows that the major shareholders can hardly obtain the dividend rights of the company, and the performance of the company has nothing to do with the major shareholders, and it is very likely to use this to hollow out the listed company. The proportion of major shareholders' equity pledge is relatively high. If the supplementary pledge or pledge can not be carried out in the later period, it is likely to cause the transfer of the company's control right, which will have an adverse impact on the company's value.

\section{Disscussion}

Improve the relevant laws and regulations, create a good regulatory environment for equity pledge. At present, limit the proportion of the major shareholders' equity pledge, which leads to the major shareholders' failure to obtain the corresponding external financing. Regardless of the company's future operating capacity and personal repayment conditions, the number of equity pledge is constantly expanded, and even the proportion of equity pledge is higher than the actual proportion of shareholding. Legislation first, supervision first. First of all, the CSRC should strengthen the company disclosure system, On the basis of the disclosure of information such as the quantity of the original shareholder's equity pledge, the pledge proportion, the name of the investor and the name of the pledgee, Detailed disclosure of the purpose of shareholders' equity pledge and the specific use of the funds raised [15]. Secondly, the SFC should work with banks and other relevant departments to have a comprehensive understanding of shareholders' credit and make it public to the public in a timely manner, So that investors can reasonably evaluate the debt repayment ability of shareholders, so as to protect the legitimate rights and interests of small and medium shareholders [16]. 
Standardizing internal control system and improving corporate governance environment. The company should actively establish a sound internal control system and strictly implement the rules and regulations, At the same time, small and medium-sized shareholders' right to speak at the general meeting of shareholders should be increased, Fully protect the legitimate rights and interests of every shareholder, create a good investment environment for the company, and enhance the value of the company by attracting investors.

\section{Conclusion}

This article will take La Chapelle's stock pledge business as an example, and focus on the perspective of a securities company to study and analyze the risks of stock pledge business. With the different proportion of equity pledge, the impact on the value of the company will be different.

\section{Acknowledgments}

We are grateful for the financial support from the Social Science Project (No. 17YJC630177).

\section{References}

1. Jin, R., Chen, M., Luo, H. (2019) Research on the causes and economic consequences of equity pledge of Private Listed Companies., J. China market., 20: 29-30.

2. Ma,Y.,An, X, Q.,(2018) Exchange Rate Changes, Income Gap, and Economic Growth: Based on Empirical Research in Different Stages of Economic Development., J.Economist.,9:78-87.

3. Jiang, X, W., (2019) The Influence of Controlling Shareholder's Equity Pledge on Enterprise Innovation Efficiency., J. Friends of Accounting., 24: 23-29.

4. Ming, Y., Zhang, Q., (2020) Pledge of Controlling Shareholders' Equity: Research Review and Prospect.,J. Journal of Hubei University of Economics.,3:97-110.

5. Li, C, Q., Xing, W., (2018) Pledge of controlling shareholder's equity affects executive compensation-is performance sensitive?,J. Economic management.,5:157-174.

6. Chen, X., Chu, W. (2019) Risk analysis and preventive measures of Stock Pledge under the background of financial deleveraging -- Taking Shanghai and Shenzhen A-share listed companies as an example., J. Western finance., 1: 16-21.

7. Dai, Z, X., (2018) A Brief Discussion on the Risks and Countermeasures Existing in the Pledge of Large Shareholders of Listed Companies., J. Economist., 1:86-87.

8. Chen, N.,(2017) Research on the Ways and Significance of Strengthening Enterprise Capital
Risk Management and Control., J. Modern economic information., 5:212.

9. Wang, X., Xiao, Y. (2018) Empirical Study on the impact of stock pledge announcement on the market value of the company., J. Development research, 2: 154-160.

10. Shen, P., Jing, R., (2020) Summary and Prospects of Related Research on Equity Pledge., J. Finance and Accounting Monthly,3:16-23.

11. Wen, W.,(2018) Research on the Influence of Controlling Shareholder's Equity Pledge on Enterprise Innovation., J. Journal of Management, 7:998-1008

12. Wang, X., Zhang, X., Xue, Z. (2018) Research on the Impact of Large Shareholder Equity Pledge on Company Performance-Based on the Moderating Effect of Internal Control., J. Accounting Friends, 10:58-63.

13. Wang, X. (2018) The Impact of Accounting Information Disclosure Quality of my country's Listed Companies on Their Financing., J, Information System Engineering, 6: 110-111.

14. Fan, Y. (2015) Research on the Correlation between the Financing Structure and Corporate Performance of my country's Real Estate Listed Companies., J. China Real Estate, 15: 23-25.

15. Gao, W.(2018) Does the pledge of major shareholders' equity affect the bank loans of listed companies?, J. Financial Supervision Research., 10: 49-64.

16. Tang, X.(2015)A Legal Analysis of the Protection of Minority Shareholders' Rights and Interests, J. Journal of Guizhou University (Social Science Edition).,8: 60-65. 